\title{
Pattern recognition receptors (version 2019.4) in the IUPHAR/BPS Guide to Pharmacology Database
}

\author{
Clare Bryant ${ }^{1}$ and Tom P. Monie ${ }^{1}$ \\ 1. University of Cambridge, UK
}

\begin{abstract}
Pattern Recognition Receptors (PRRs, [83]) (nomenclature as agreed by NC-IUPHAR sub-committee on Pattern Recognition Receptors, [15]) participate in the innate immune response to microbial agents, the stimulation of which leads to activation of intracellular enzymes and regulation of gene transcription. PRRs express multiple leucine-rich regions to bind a range of microbially-derived ligands, termed PAMPs or pathogenassociated molecular patterns or endogenous ligands, termed DAMPS or damage-associated molecular patterns. These include peptides, carbohydrates, peptidoglycans, lipoproteins, lipopolysaccharides, and nucleic acids. PRRs include both cell-surface and intracellular proteins. PRRs may be divided into signalling-associated members, identified here, and endocytic members, the function of which appears to be to recognise particular microbial motifs for subsequent cell attachment, internalisation and destruction. Some are involved in inflammasome formation, and modulation of IL-1 $\beta$ cleavage and secretion, and others in the initiation of the type I interferon response.
\end{abstract}

PRRs included in the Guide To PHARMACOLOGY are:

Catalytic PRRs (see links below this overview)

Toll-like receptors (TLRs)

Nucleotide-binding oligomerization domain, leucine-rich repeat containing receptors (NLRs, also known as NOD (Nucleotide oligomerisation domain)-like receptors)

RIG-I-like receptors (RLRs)

Caspase 4 and caspase 5

\section{Non-catalytic PRRs}

Absent in melanoma (AIM)-like receptors (ALRs)

C-type lectin-like receptors (CLRs)

Other pattern recognition receptors

Advanced glycosylation end-product specific receptor (RAGE)

\section{Contents}

This is a citation summary for Pattern recognition receptors in the Guide to Pharmacology database (GtoPdb). It exists purely as an adjunct to the database to facilitate the recognition of citations to and from the database by citation analyzers. Readers will almost certainly want to visit the relevant sections of the database which are given here under database links. 
GtoPdb is an expert-driven guide to pharmacological targets and the substances that act on them. GtoPdb is a reference work which is most usefully represented as an on-line database. As in any publication this work should be appropriately cited, and the papers it cites should also be recognized. This document provides a citation for the relevant parts of the database, and also provides a reference list for the research cited by those parts.

Please note that the database version for the citations given in GtoPdb are to the most recent preceding version in which the family or its subfamilies and targets were substantially changed. The links below are to the current version. If you need to consult the cited version, rather than the most recent version, please contact the GtoPdb curators.

\section{Database links}

Pattern recognition receptors

http://www.guidetopharmacology.org/GRAC/FamilyDisplayForward?familyld=302

Toll-like receptor family

http://www.guidetopharmacology.org/GRAC/FamilyDisplayForward?familyld=316

Receptors

TLR1

http://www.guidetopharmacology.org/GRAC/ObjectDisplayForward?objectld=1751

TLR2

http://www.guidetopharmacology.org/GRAC/ObjectDisplayForward?objectld=1752

TLR3

http://www.guidetopharmacology.org/GRAC/ObjectDisplayForward?objectld=1753

TLR4

http://www.guidetopharmacology.org/GRAC/ObjectDisplayForward?objectld=1754

TLR5

http://www.guidetopharmacology.org/GRAC/ObjectDisplayForward?objectld=1755

TLR6

http://www.guidetopharmacology.org/GRAC/ObjectDisplayForward?objectld=1756

TLR7

http://www.guidetopharmacology.org/GRAC/ObjectDisplayForward?objectld=1757

TLR8

http://www.guidetopharmacology.org/GRAC/ObjectDisplayForward?objectld=1758

TLR9

http://www.guidetopharmacology.org/GRAC/ObjectDisplayForward?objectld=1759

TLR10

http://www.guidetopharmacology.org/GRAC/ObjectDisplayForward?objectld=1760

TLR11

http://www.guidetopharmacology.org/GRAC/ObjectDisplayForward?objectld=1761

NOD-like receptor family

http://www.guidetopharmacology.org/GRAC/FamilyDisplayForward?familyld=317

Receptors

NOD1 (nucleotide binding oligomerization domain containing 1)

http://www.guidetopharmacology.org/GRAC/ObjectDisplayForward?objectld=1762

NOD2(nucleotide binding oligomerization domain containing 2)

http://www.guidetopharmacology.org/GRAC/ObjectDisplayForward?objectld=1763

NLRC3

http://www.guidetopharmacology.org/GRAC/ObjectDisplayForward?objectld=1764

NLRC4

http://www.guidetopharmacology.org/GRAC/ObjectDisplayForward?objectld=1782 


\section{NLRC5}

http://www.guidetopharmacology.org/GRAC/ObjectDisplayForward?objectld=1765 NLRX1

http://www.guidetopharmacology.org/GRAC/ObjectDisplayForward?objectld=1766

CIITA

http://www.guidetopharmacology.org/GRAC/ObjectDisplayForward?objectld=1767

NLRP1

http://www.guidetopharmacology.org/GRAC/ObjectDisplayForward?objectld=1768

NLRP2

http://www.guidetopharmacology.org/GRAC/ObjectDisplayForward?objectld=1769

NLRP3

http://www.guidetopharmacology.org/GRAC/ObjectDisplayForward?objectld=1770

NLRP4

http://www.guidetopharmacology.org/GRAC/ObjectDisplayForward?objectld=1771

NLRP5

http://www.guidetopharmacology.org/GRAC/ObjectDisplayForward?objectld=1772

NLRP6

http://www.guidetopharmacology.org/GRAC/ObjectDisplayForward?objectld=1773

NLRP7

http://www.guidetopharmacology.org/GRAC/ObjectDisplayForward?objectld=1774

NLRP8

http://www.guidetopharmacology.org/GRAC/ObjectDisplayForward?objectld=1775

NLRP9

http://www.guidetopharmacology.org/GRAC/ObjectDisplayForward?objectld=1776

NLRP10

http://www.guidetopharmacology.org/GRAC/ObjectDisplayForward?objectld=1777

NLRP11

http://www.guidetopharmacology.org/GRAC/ObjectDisplayForward?objectld=1778

NLRP12

http://www.guidetopharmacology.org/GRAC/ObjectDisplayForward?objectld=1779

NLRP13

http://www.guidetopharmacology.org/GRAC/ObjectDisplayForward?objectld=1780

NLRP14

http://www.guidetopharmacology.org/GRAC/ObjectDisplayForward?objectld=1781

RIG-I-like receptor family

http://www.guidetopharmacology.org/GRAC/FamilyDisplayForward?familyld=940

Receptors

RIG-1(DExD/H-box helicase 58)

http://www.guidetopharmacology.org/GRAC/ObjectDisplayForward?objectld=2920

MDA5(interferon induced with helicase $C$ domain 1)

http://www.guidetopharmacology.org/GRAC/ObjectDisplayForward?objectld=2921

LGP2(DExH-box helicase 58)

http://www.guidetopharmacology.org/GRAC/ObjectDisplayForward?objectld=2922

\section{References}

1. (2006) CpG 7909: PF 3512676, PF-3512676. Drugs R D 7: 312-6 [PMID:16922592]

2. Adams JL, Smothers J, Srinivasan R and Hoos A. (2015) Big opportunities for small molecules in immunooncology. Nat Rev Drug Discov 14: 603-22 [PMID:26228631]

3. Ahlers LR and Goodman AG. (2016) Nucleic acid sensing and innate immunity: signaling pathways controlling viral pathogenesis and autoimmunity. Curr Clin Microbiol Rep 3: 132-141 [PMID:27857881] 
4. Akira S and Takeda K. (2004) Toll-like receptor signalling.Nat. Rev. Immunol. 4: 499-511 [PMID:15229469]

5. Akiyama M, Takeichi T, McGrath JA and Sugiura K. (2017) Autoinflammatory keratinization diseases.J. Allergy Clin. Immunol. 140: 1545-1547 [PMID:28668225]

6. Alexopoulou L, Holt AC, Medzhitov R and Flavell RA. (2001) Recognition of double-stranded RNA and activation of NF-kappaB by Toll-like receptor 3. Nature 413: 732-8 [PMID:11607032]

7. Babdor J, Descamps D, Adiko AC, Tohmé M, Maschalidi S, Evnouchidou I, Vasconcellos LR, De Luca M, Mauvais FX and Garfa-Traore M et al.. (2017) IRAP' endosomes restrict TLR9 activation and signaling. Nat. Immunol. 18: 509-518 [PMID:28319098]

8. Baldwin AG, Brough D and Freeman S. (2016) Inhibiting the Inflammasome: A Chemical Perspective.J. Med. Chem. 59: 1691-710 [PMID:26422006]

9. Barochia A, Solomon S, Cui X, Natanson C and Eichacker PQ. (2011) Eritoran tetrasodium (E5564) treatment for sepsis: review of preclinical and clinical studies. Expert Opin Drug Metab Toxicol7: 479-94 [PMID:21323610]

10. Beutler B, Du X and Poltorak A. (2001) Identification of Toll-like receptor 4 (TIr4) as the sole conduit for LPS signal transduction: genetic and evolutionary studies. J. Endotoxin Res. 7: 277-80 [PMID:11717581]

11. Biggadike K, Ahmed M, Ball DI, Coe DM, Dalmas Wilk DA, Edwards CD, Gibbon BH, Hardy CJ, Hermitage SA and Hessey JO et al.. (2016) Discovery of 6-Amino-2-\{[(1S)-1-methylbutyl]oxy\}-9-[5-(1piperidinyl)pentyl]-7,9-dihydro-8H-purin-8-one (GSK2245035), a Highly Potent and Selective Intranasal Toll-Like Receptor 7 Agonist for the Treatment of Asthma. J. Med. Chem. 59: 1711-26 [PMID:26861551]

12. Bleda S and de Haro J. (2018) Identification of a potential inhibitor of NLRP1 inflammasome for the treatment of peripheral arterial disease. Int. J. Cardiol. 256: 30 [PMID:29454411]

13. Bleda S, de Haro J, Varela C, Ferruelo A and Acin F. (2016) Elevated levels of triglycerides and vldlcholesterol provoke activation of nlrp1 inflammasome in endothelial cells. Int. J. Cardiol. 220: 52-5 [PMID:27372042]

14. Bruns AM and Horvath CM. (2014) Antiviral RNA recognition and assembly by RLR family innate immune sensors. Cytokine Growth Factor Rev. 25: 507-12 [PMID:25081315]

15. Bryant CE, Orr S, Ferguson B, Symmons MF, Boyle JP and Monie TP. (2015) International Union of Basic and Clinical Pharmacology. XCVI. Pattern recognition receptors in health and disease. Pharmacol. Rev. 67: $462-504$ [PMID:25829385]

16. Chamaillard M, Girardin SE, Viala J and Philpott DJ. (2003) Nods, Nalps and Naip: intracellular regulators of bacterial-induced inflammation. Cell. Microbiol. 5: 581-92 [PMID:12925128]

17. Chan M, Hayashi T, Mathewson RD, Nour A, Hayashi Y, Yao S, Tawatao RI, Crain B, Tsigelny IF and Kouznetsova VL et al.. (2013) Identification of substituted pyrimido[5,4-b]indoles as selective Toll-like receptor 4 ligands. J. Med. Chem. 56: 4206-23 [PMID:23656327]

18. Chavarría-Smith J and Vance RE. (2015) The NLRP1 inflammasomes. Immunol. Rev. 265: 22-34 [PMID:25879281]

19. Coll RC, Robertson AA, Chae JJ, Higgins SC, Muñoz-Planillo R, Inserra MC, Vetter I, Dungan LS, Monks BG and Stutz A et al.. (2015) A small-molecule inhibitor of the NLRP3 inflammasome for the treatment of inflammatory diseases. Nat. Med. 21: 248-55 [PMID:25686105]

20. Cui J, Zhu L, Xia X, Wang HY, Legras X, Hong J, Ji J, Shen P, Zheng S and Chen Zæt al.. (2010) NLRC5 negatively regulates the NF-kappaB and type I interferon signaling pathways. Cell 141: 483-96 [PMID:20434986]

21. Davis BK, Wen H and Ting JP. (2011) The inflammasome NLRs in immunity, inflammation, and associated diseases. Annu. Rev. Immunol. 29: 707-35 [PMID:21219188]

22. Dellacasagrande J. (2011) Humanised antibodies to toll-like receptor 2 and uses thereof Patent number: WO2011003925.

23. Dodé C, Le Dû N, Cuisset L, Letourneur F, Berthelot JM, Vaudour G, Meyrier A, Watts RA, Scott DG and Nicholls A et al.. (2002) New mutations of CIAS1 that are responsible for Muckle-Wells syndrome and familial cold urticaria: a novel mutation underlies both syndromes. Am. J. Hum. Genet. 70: 1498-506 
[PMID:11992256]

24. Farhat K, Riekenberg S, Heine H, Debarry J, Lang R, Mages J, Buwitt-Beckmann U, Röschmann K, Jung $\mathrm{G}$ and Wiesmüller KH et al.. (2008) Heterodimerization of TLR2 with TLR1 or TLR6 expands the ligand spectrum but does not lead to differential signaling. J. Leukoc. Biol. 83: 692-701 [PMID:18056480]

25. Garay RP, Viens P, Bauer J, Normier G, Bardou M, Jeannin JF and Chiavaroli C. (2007) Cancer relapse under chemotherapy: why TLR2/4 receptor agonists can help. Eur. J. Pharmacol. 563: 1-17 [PMID:17383632]

26. Grandemange S, Sanchez E, Louis-Plence P, Tran Mau-Them F, Bessis D, Coubes C, Frouin E, Seyger M, Girard $M$ and Puechberty J et al.. (2017) A new autoinflammatory and autoimmune syndrome associated with NLRP1 mutations: NAIAD (NLRP1-associated autoinflammation with arthritis and dyskeratosis). Ann. Rheum. Dis. 76: 1191-1198 [PMID:27965258]

27. Harton JA and Ting JP. (2000) Class II transactivator: mastering the art of major histocompatibility complex expression. Mol. Cell. Biol. 20: 6185-94 [PMID:10938095]

28. Hayashi F, Smith KD, Ozinsky A, Hawn TR, Yi EC, Goodlett DR, Eng JK, Akira S, Underhill DM and Aderem A. (2001) The innate immune response to bacterial flagellin is mediated by Toll-like receptor 5 . Nature 410: 1099-103 [PMID:11323673]

29. Heil F, Ahmad-Nejad P, Hemmi H, Hochrein H, Ampenberger F, Gellert T, Dietrich H, Lipford G, Takeda K and Akira S et al.. (2003) The Toll-like receptor 7 (TLR7)-specific stimulus loxoribine uncovers a strong relationship within the TLR7, 8 and 9 subfamily. Eur. J. Immunol. 33: 2987-97 [PMID:14579267]

30. Hemmi H, Kaisho T, Takeuchi O, Sato S, Sanjo H, Hoshino K, Horiuchi T, Tomizawa H, Takeda K and Akira S. (2002) Small anti-viral compounds activate immune cells via the TLR7 MyD88-dependent signaling pathway. Nat. Immunol. 3: 196-200 [PMID:11812998]

31. Hemmi H, Takeuchi O, Kawai T, Kaisho T, Sato S, Sanjo H, Matsumoto M, Hoshino K, Wagner $\mathrm{H}$ and Takeda K et al.. (2000) A Toll-like receptor recognizes bacterial DNA.Nature 408: 740-5 [PMID:11130078]

32. Henao-Mejia J, Elinav E, Jin C, Hao L, Mehal WZ, Strowig T, Thaiss CA, Kau AL, Eisenbarth SC and Jurczak MJ et al.. (2012) Inflammasome-mediated dysbiosis regulates progression of NAFLD and obesity. Nature 482: 179-85 [PMID:22297845]

33. Hoffman HM, Mueller JL, Broide DH, Wanderer AA and Kolodner RD. (2001) Mutation of a new gene encoding a putative pyrin-like protein causes familial cold autoinflammatory syndrome and Muckle-Wells syndrome. Nat. Genet. 29: 301-5 [PMID:11687797]

34. Hozumi H, Fujisawa T, Nakashima R, Johkoh T, Sumikawa H, Murakami A, Enomoto N, Inui N, Nakamura $\mathrm{Y}$ and Hosono $\mathrm{Y}$ et al.. (2016) Comprehensive assessment of myositis-specific autoantibodies in polymyositis/dermatomyositis-associated interstitial lung disease. Respir Med 121: 91 -99 [PMID:27888997]

35. Huynh AS, Chung WJ, Cho HI, Moberg VE, Celis E, Morse DL and Vagner J. (2012) Novel toll-like receptor 2 ligands for targeted pancreatic cancer imaging and immunotherapy. J. Med. Chem. 55: 9751-62 [PMID:23098072]

36. li M, Matsunaga N, Hazeki K, Nakamura K, Takashima K, Seya T, Hazeki O, Kitazaki T and lizawa Y. (2006) A novel cyclohexene derivative, ethyl (6R)-6-[N-(2-Chloro-4-fluorophenyl)sulfamoyl]cyclohex-1-ene1-carboxylate (TAK-242), selectively inhibits toll-like receptor 4-mediated cytokine production through suppression of intracellular signaling. Mol. Pharmacol. 69: 1288-95 [PMID:16373689]

37. Imamura R, Wang Y, Kinoshita T, Suzuki M, Noda T, Sagara J, Taniguchi S, Okamoto H and Suda T. (2010) Anti-inflammatory activity of PYNOD and its mechanism in humans and mice. J. Immunol. 184: 5874-84 [PMID:20393137]

38. Ingalls RR, Monks BG, Savedra R, Christ WJ, Delude RL, Medvedev AE, Espevik T and Golenbock DT. (1998) CD11/CD18 and CD14 share a common lipid A signaling pathway. J. Immunol. 161: 5413-20 [PMID:9820516]

39. Jeong E and Lee JY. (2011) Intrinsic and extrinsic regulation of innate immune receptors. Yonsei Med. J. 52: 379-92 [PMID:21488180]

40. Jerala R. (2007) Structural biology of the LPS recognition.Int. J. Med. Microbiol. 297: 353-63 [PMID:17481951] 
41. Jiang $\mathrm{H}, \mathrm{He} \mathrm{H}$, Chen Y, Huang W, Cheng J, Ye J, Wang A, Tao J, Wang $\mathrm{C}$ and Liu @t al.. (2017) Identification of a selective and direct NLRP3 inhibitor to treat inflammatory disorders. J. Exp. Med. 214: 3219-3238 [PMID:29021150]

42. Jurk M, Heil F, Vollmer J, Schetter C, Krieg AM, Wagner H, Lipford G and Bauer S. (2002) Human TLR7 or TLR8 independently confer responsiveness to the antiviral compound R-848. Nat. Immunol. 3: 499 [PMID:12032557]

43. Karki R, Man SM and Kanneganti TD. (2017) Inflammasomes and Cancer.Cancer Immunol Res 5: 94-99 [PMID:28093447]

44. Kawasaki K, Akashi S, Shimazu R, Yoshida T, Miyake K and Nishijima M. (2000) Mouse toll-like receptor 4.MD-2 complex mediates lipopolysaccharide-mimetic signal transduction by Taxol. J. Biol. Chem. 275: 2251-4 [PMID:10644670]

45. Khan PM, Correa RG, Divilianska DB, Peddibhotla S, Sessions EH, Magnuson G, Brown B, Suyama E, Yuan $\mathrm{H}$ and Mangravita-Nov A et al.. (2011) Identification of Inhibitors of NOD1-Induced Nuclear Factor-kB Activation. ACS Med Chem Lett. 2: 780-785 [PMID:22003428]

46. Kuenzel S, Till A, Winkler M, Häsler R, Lipinski S, Jung S, Grötzinger J, Fickenscher H, Schreiber S and Rosenstiel P. (2010) The nucleotide-binding oligomerization domain-like receptor NLRC5 is involved in IFN-dependent antiviral immune responses. J. Immunol. 184: 1990-2000 [PMID:20061403]

47. Lamphier M, Zheng W, Latz E, Spyvee M, Hansen H, Rose J, Genest M, Yang H, Shaffer C and Zhao Yet al.. (2014) Novel small molecule inhibitors of TLR7 and TLR9: mechanism of action and efficacy in vivo. Mol. Pharmacol. 85: 429-40 [PMID:24342772]

48. Larson P, Kucaba TA, Xiong Z, Olin M, Griffith TS and Ferguson DM.. (2017) Design and Synthesis of N1Modified Imidazoquinoline Agonists for Selective Activation of Toll-like Receptors 7 and 8 ACS Med. Chem. Lett.

49. LeibundGut-Landmann S, Waldburger JM, Krawczyk M, Otten LA, Suter T, Fontana A, Acha-Orbea H and Reith W. (2004) Mini-review: Specificity and expression of CIITA, the master regulator of MHC class II genes. Eur. J. Immunol. 34: 1513-25 [PMID:15162420]

50. Li L, Yu H, Jiang Y, Deng B, Bai L, Kijlstra A and Yang P. (2016) Genetic Variations of NLR family genes in Behcet's Disease. Sci Rep 6: 20098 [PMID:26833430]

51. Liu YR, Yan X, Yu HX, Yao Y, Wang JQ, Li XF, Chen RN, Xu QQ, Ma TT and Huang Cet al.. (2017) NLRC5 promotes cell proliferation via regulating the NF-KB signaling pathway in Rheumatoid arthritis. Mol. Immunol. 91: 24-34 [PMID:28865311]

52. Lu H, Dietsch GN, Matthews MA, Yang Y, Ghanekar S, Inokuma M, Suni M, Maino VC, Henderson KE and Howbert JJ et al.. (2012) VTX-2337 is a novel TLR8 agonist that activates NK cells and augments ADCC. Clin. Cancer Res. 18: 499-509 [PMID:22128302]

53. Lucas K and Maes M. (2013) Role of the Toll Like receptor (TLR) radical cycle in chronic inflammation: possible treatments targeting the TLR4 pathway. Mol. Neurobiol. 48: 190-204 [PMID:23436141]

54. Mach B, Steimle V and Reith W. (1994) MHC class II-deficient combined immunodeficiency: a disease of gene regulation. Immunol. Rev. 138: 207-21 [PMID:8070816]

55. Mangan MS and Latz E. (2014) NLRC3 puts the brakes on STING.Immunity 40: 305-6 [PMID:24656040]

56. Mangan MSJ, Olhava EJ, Roush WR, Seidel HM, Glick GD and Latz E. (2018) Targeting the NLRP3 inflammasome in inflammatory diseases. Nat Rev Drug Discov 17: 688 [PMID:30116046]

57. Marchetti C, Swartzwelter B, Gamboni F, Neff CP, Richter K, Azam T, Carta S, Tengesdal I, Nemkov T and D'Alessandro A et al.. (2018) OLT1177, a $\beta$-sulfonyl nitrile compound, safe in humans, inhibits the NLRP3 inflammasome and reverses the metabolic cost of inflammation. Proc. Natl. Acad. Sci. U.S.A.115: E1530-E1539 [PMID:29378952]

58. Martinon F, Pétrilli V, Mayor A, Tardivel A and Tschopp J. (2006) Gout-associated uric acid crystals activate the NALP3 inflammasome. Nature 440: 237-41 [PMID:16407889]

59. Matsumiya T and Stafforini DM. (2010) Function and regulation of retinoic acid-inducible gene-I.Crit. Rev. Immunol. 30: 489-513 [PMID:21175414]

60. Maver A, Lavtar P, Ristić S, Stopinšek S, Simčič S, Hočevar K, Sepčić J, Drulović J, Pekmezović T and 
Novaković I et al.. (2017) Identification of rare genetic variation of NLRP1 gene in familial multiple sclerosis. Sci Rep 7: 3715 [PMID:28623311]

61. Miao EA, Andersen-Nissen E, Warren SE and Aderem A. (2007) TLR5 and Ipaf: dual sensors of bacterial flagellin in the innate immune system. Semin Immunopathol 29: 275-88 [PMID:17690885]

62. Milam EC, Futran J and Franks Jr AG. (2016) Anti-MDA5 Antibody Dermatomyositis Overlap with Systemic Lupus Erythematosus: A Case Report and Review of the Literature. Open Rheumatol J 10: 122-128 [PMID:28077979]

63. Nakamura T, Wada H, Kurebayashi H, McInally T, Bonnert R and Isobe Y. (2013) Synthesis and evaluation of 8-oxoadenine derivatives as potent Toll-like receptor 7 agonists with high water solubility. Bioorg. Med. Chem. Lett. 23: 669-72 [PMID:23265901]

64. Nakao Y, Funami K, Kikkawa S, Taniguchi M, Nishiguchi M, Fukumori Y, Seya T and Matsumoto M. (2005) Surface-expressed TLR6 participates in the recognition of diacylated lipopeptide and peptidoglycan in human cells. J. Immunol. 174: 1566-73 [PMID:15661917]

65. Neerincx A, Lautz K, Menning M, Kremmer E, Zigrino $P$, Hösel M, Büning H, Schwarzenbacher $R$ and Kufer TA. (2010) A role for the human nucleotide-binding domain, leucine-rich repeat-containing family member NLRC5 in antiviral responses. J. Biol. Chem. 285: 26223-32 [PMID:20538593]

66. Ohashi K, Burkart V, Flohé S and Kolb H. (2000) Cutting edge: heat shock protein 60 is a putative endogenous ligand of the toll-like receptor-4 complex. J. Immunol. 164: 558-61 [PMID:10623794]

67. Oosting M, Cheng SC, Bolscher JM, Vestering-Stenger R, Plantinga TS, Verschueren IC, Arts P, Garritsen A, van Eenennaam $\mathrm{H}$ and Sturm $\mathrm{P}$ et al.. (2014) Human TLR10 is an anti-inflammatory pattern-recognition receptor. Proc. Natl. Acad. Sci. U.S.A. 111: E4478-84 [PMID:25288745]

68. Pan Y, Wang Y, Xu J, Wu J, Chen Q, Zeng G and Zhao G. (2017) TG and VLDL cholesterol activate NLRP1 inflammasome by Nuclear Factor-KB in endothelial cells. Int. J. Cardiol. 234: 103 [PMID:28062143]

69. Park BS, Song DH, Kim HM, Choi BS, Lee H and Lee JO. (2009) The structural basis of lipopolysaccharide recognition by the TLR4-MD-2 complex. Nature 458: 1191-5 [PMID:19252480]

70. Peri F and Calabrese V. (2014) Toll-like receptor 4 (TLR4) modulation by synthetic and natural compounds: an update. J. Med. Chem. 57: 3612-22 [PMID:24188011]

71. Place DE and Kanneganti TD. (2018) Recent advances in inflammasome biology.Curr. Opin. Immunol. 50: 32-38 [PMID:29128729]

72. Plantinga TS, Johnson MD, Scott WK, van de Vosse E, Velez Edwards DR, Smith PB, Alexander BD, Yang JC, Kremer D and Laird GM et al.. (2012) Toll-like receptor 1 polymorphisms increase susceptibility to candidemia. J. Infect. Dis. 205: 934-43 [PMID:22301633]

73. Poltorak A, He X, Smirnova I, Liu MY, Van Huffel C, Du X, Birdwell D, Alejos E, Silva M and Galanos Cet al.. (1998) Defective LPS signaling in C3H/HeJ and C57BL/10ScCr mice: mutations in TIr4 gene.Science 282: 2085-8 [PMID:9851930]

74. Sabbah A, Chang TH, Harnack R, Frohlich V, Tominaga K, Dube PH, Xiang Y and Bose S. (2009) Activation of innate immune antiviral responses by Nod2. Nat. Immunol. 10: 1073-80 [PMID:19701189]

75. Salunke DB, Yoo E, Shukla NM, Balakrishna R, Malladi SS, Serafin KJ, Day VW, Wang X and David SA. (2012) Structure-activity relationships in human Toll-like receptor 8-active 2,3-diamino-furo[2,3-c]pyridines. J. Med. Chem. 55: 8137-51 [PMID:22924757]

76. Saresella M, La Rosa F, Piancone F, Zoppis M, Marventano I, Calabrese E, Rainone V, Nemni R, Mancuso R and Clerici M. (2016) The NLRP3 and NLRP1 inflammasomes are activated in Alzheimer's disease. Mol Neurodegener 11: 23 [PMID:26939933]

77. Scholl T, Mahanta SK and Strominger JL. (1997) Specific complex formation between the type II bare lymphocyte syndrome-associated transactivators CIITA and RFX5. Proc. Natl. Acad. Sci. U.S.A. 94: 63304 [PMID:9177217]

78. Schroder K and Tschopp J. (2010) The inflammasomes. Cell 140: 821-32 [PMID:20303873]

79. Schwandner R, Dziarski R, Wesche H, Rothe M and Kirschning CJ. (1999) Peptidoglycan- and lipoteichoic acid-induced cell activation is mediated by toll-like receptor 2. J. Biol. Chem. 274: 17406-9

[PMID:10364168] 
80. Sharma $N$ and Jha S. (2016) NLR-regulated pathways in cancer: opportunities and obstacles for therapeutic interventions. Cell. Mol. Life Sci. 73: 1741-64 [PMID:26708292]

81. Shimazu R, Akashi S, Ogata H, Nagai Y, Fukudome K, Miyake K and Kimoto M. (1999) MD-2, a molecule that confers lipopolysaccharide responsiveness on Toll-like receptor 4. J. Exp. Med. 189: 1777-82 [PMID:10359581]

82. Sönmez HE and Özen S. (2017) A clinical update on inflammasomopathies.Int. Immunol. 29: 393-400 [PMID:28387826]

83. Takeuchi $O$ and Akira S. (2010) Pattern recognition receptors and inflammation.Cell 140: 805-20 [PMID:20303872]

84. Takeuchi O, Kawai T, Mühlradt PF, Morr M, Radolf JD, Zychlinsky A, Takeda K and Akira S. (2001) Discrimination of bacterial lipoproteins by Toll-like receptor 6. Int. Immunol. 13: 933-40 [PMID:11431423]

85. Takeuchi O, Sato S, Horiuchi T, Hoshino K, Takeda K, Dong Z, Modlin RL and Akira S. (2002) Cutting edge: role of Toll-like receptor 1 in mediating immune response to microbial lipoproteins. J. Immunol. 169: 10-4 [PMID:12077222]

86. Tarafdar A, Hopcroft LE, Gallipoli P, Pellicano F, Cassels J, Hair A, Korfi K, Jørgensen HG, Vetrie D and Holyoake TL et al.. (2017) CML cells actively evade host immune surveillance through cytokine-mediated downregulation of MHC-II expression. Blood 129: 199-208 [PMID:27793879]

87. Ting JP, Lovering RC, Alnemri ES, Bertin J, Boss JM, Davis BK, Flavell RA, Girardin SE, Godzik A and Harton JA et al.. (2008) The NLR gene family: a standard nomenclature.Immunity 28: 285-7 [PMID:18341998]

88. Uematsu S and Akira S. (2008) Toll-Like receptors (TLRs) and their ligands.Handb Exp Pharmacol 1-20 [PMID:18071652]

89. Wang W, Wang C, Gong $Y$ and Zhang X. (2018) Inhibition of NLRP1 inflammasome might be a novel therapeutic target in the treatment of peripheral arterial disease. Int. J. Cardiol. 256: 29 [PMID:29454409]

90. Wang Y, Su L, Morin MD, Jones BT, Whitby LR, Surakattula MM, Huang H, Shi H, Choi JH and Wang KW et al.. (2016) TLR4/MD-2 activation by a synthetic agonist with no similarity to LPS.Proc. Natl. Acad. Sci. U.S.A. 113: E884-93 [PMID:26831104]

91. Westerveld GH, Korver CM, van Pelt AM, Leschot NJ, van der Veen F, Repping S and Lombardi MP. (2006) Mutations in the testis-specific NALP14 gene in men suffering from spermatogenic failure. Hum. Reprod. 21: 3178-84 [PMID:16931801]

92. Yau AC, Piehl F, Olsson T and Holmdahl R. (2017) Effects of C2ta genetic polymorphisms on MHC class II expression and autoimmune diseases. Immunology 150: 408-417 [PMID:27861821]

93. Yoshimura A, Lien E, Ingalls RR, Tuomanen E, Dziarski R and Golenbock D. (1999) Cutting edge: recognition of Gram-positive bacterial cell wall components by the innate immune system occurs via Tolllike receptor 2. J. Immunol. 163: 1-5 [PMID:10384090]

94. Yu CH, Moecking J, Geyer M and Masters SL. (2018) Mechanisms of NLRP1-Mediated Autoinflammatory Disease in Humans and Mice. J. Mol. Biol. 430: 142-152 [PMID:28733143]

95. Zhai Z, Liu W, Kaur M, Luo Y, Domenico J, Samson JM, Shellman YG, Norris DA, Dinarello CA and Spritz RA et al.. (2017) NLRP1 promotes tumor growth by enhancing inflammasome activation and suppressing apoptosis in metastatic melanoma. Oncogene 36: 3820-3830 [PMID:28263976]

96. Zhang L, Mo J, Swanson KV, Wen H, Petrucelli A, Gregory SM, Zhang Z, Schneider M, Jiang Y and Fitzgerald KA et al.. (2014) NLRC3, a member of the NLR family of proteins, is a negative regulator of innate immune signaling induced by the DNA sensor STING. Immunity 40: 329-41 [PMID:24560620]

97. Zhang S, Hu Z, Tanji H, Jiang S, Das N, Li J, Sakaniwa K, Jin J, Bian Y and Ohto lфt al.. (2018) Smallmolecule inhibition of TLR8 through stabilization of its resting state. Nat. Chem. Biol. 14: 58-64 [PMID:29155428]

98. Zhong FL, Mamaï O, Sborgi L, Boussofara L, Hopkins R, Robinson K, Szeverényi I, Takeichi T, Balaji R and Lau A et al.. (2016) Germline NLRP1 Mutations Cause Skin Inflammatory and Cancer Susceptibility Syndromes via Inflammasome Activation. Cell 167: 187-202.e17 [PMID:27662089] 
